\title{
Impact of Foreign Aid on Economic Growth of Nepal: An Empirical Evidence
}

\author{
Christina Pradhan ${ }^{1}$, Ram Kumar Phuyal ${ }^{2,3, *}$ \\ ${ }^{1}$ Ace Institute of Management (AIM), Pokhara University, Pokhara, Nepal \\ ${ }^{2}$ Centre for Economic Development and Administration (CEDA), Tribhuvan University, Kirtipur, Nepal \\ ${ }^{3}$ National Planning Commission (NPC), Government of Nepal, Kathmandu, Nepal
}

Email address:

phuyal_ram5@yahoo.com (R. K. Phuyal)

${ }^{*}$ Corresponding author

\section{To cite this article:}

Christina Pradhan, Ram Kumar Phuyal. Impact of Foreign Aid on Economic Growth of Nepal: An Empirical Evidence. International Journal of Finance and Banking Research. Vol. 6, No. 3, 2020, pp. 44-50. doi: 10.11648/j.ijfbr.20200603.12

Received: February 24, 2020; Accepted: April 20, 2020; Published: May 28, 2020

\begin{abstract}
This paper examines the impact of foreign aid on economic growth in Nepal by considering time series data of the last forty years from 1975/76 to 2015/16. Foreign aid's impact on Nepalese economy was explored with Gross Domestic Product (GDP) as the dependent variable against few selected independent variables such as foreign aid, remittance, investment, labor force and lagged GDP. The study used partial adjustment model to analyze the impact of foreign aid on economic growth and further applied Chow test to examine whether there is a structural breakthrough in the economy. The results indicate that foreign aid has a positive relationship with GDP. However, the relation is not significant since higher volume of foreign aid seems to be used in humanitarian and social welfare rather than production activities in the real sectors. From the Chow test, it was found that foreign aid- GDP relationship has not undergone a structural breakthrough in Nepal over the last forty years' period. In light of such empirical findings, it is suggested to the government policy makers to allocate the foreign aid on productive sectors and human capital formation activities with special focus on capital expenditures to achieve the high rate of economic growth in order to meet the periodic plan and long term development goals.
\end{abstract}

Keywords: Foreign Aid, Remittance, Investment, Partial Adjustment Model

\section{Introduction}

Foreign aid to developing countries has been an important source of development finance in the form of grants, concessional loans for development projects, and assistance for meeting humanitarian needs and emergencies for more than half a century [1-3]. Over the last 60 years, donors have provided more than $\$ 2.3$ trillion amount of foreign aid to poor countries for their developmental activities [4, 5]. Since after getting such huge significant amount of foreign aid, nearly 3 billion people still live on less than $\$ 2$ a day; 840 million are suffering from hunger, 10 million children die from various kinds of preventable diseases and 1 billion adults are still illiterate $[6,7]$.

Nepal has been one of the aids receiving country aid for more than 60 years through foreign Governments, multilateral agencies and INGOs, collectively referred as external developmental partners (EDPs). EDPs have been involved in Nepal's policy making, program design, and implementation in a range of areas [8]. Among the South Asian countries, Nepal is one of the highest aid receiving nations. During 1995-2001, foreign aid to Nepal, as a percentage of the GDP, averaged 8.68 per cent higher than that of Sri Lanka and Pakistan, who received 3.06 per cent and 2.09 per cent respectively during the same period $[9,10]$.

Despite the constant flow of foreign aid and decades of aid-financed development efforts in Nepal, it still remains one of the poorest countries in the world, with per capita income of about US\$ 752 and almost 23.8 per cent of the total population living in absolute poverty [11]. A casual observer of these facts could easily conclude that foreign aid to Nepal has not been effective, though they would not be able to say what would have happened in the absence of aid $[12,13]$. Donors have been reported as losing confidence in Nepal as a result of political interference and corruption in poverty relief efforts as 
well as the country's apparently poor capacity to utilize aid [14]. This shows that foreign aid in terms of grants and loans is being treated as a free lunch, neither affecting economic growth nor supporting for raising living standard and/ or maintaining equity among the people. Foreign grants may impose many undesirable terms and conditions while foreign loans are considered as the burden for the future generations $[15,16]$. Besides, they crowd out the trade sector of the economy [17].

The key question that both the donor and the recipient countries need to address is whether aid has any effect on economic growth of developing countries. Given the record of over 60 years, trillions of amount of foreign aid are being provided from donor countries [6]. However, its impact in economic growth is said to be negligible compared to those large sums of aid inflows. This issue has been approached from various perspectives; nevertheless, a single and definite answer still does not exist. Therefore, it is important to note the amount and type of financial aid that impacts the effectiveness of available funds.

The debate on the relationship between foreign aid and economic growth has drawn great attention for years. Several studies are available on the role of foreign aid on economic development in international context. Some studies for instance Phuyal and Sunuwar (2018) has shown for positive impact of foreign direct investment on economic growth while few others have shown negative impact or no impact at all on growth [18]. Ram (2004) argued that not much evidence have been established to support the belief that direct foreign assistance to countries with good 'policy' will increase the impact on growth or poverty reduction in developing countries [19].

In the global context, Durbarry, Gemmell \& Grenaway (1998) assessed the impact of foreign aid on 68 developing countries over a period of 1970-1993 and observed foreign aid have some positive impact on growth depending on macro policy environment [20]. Moreira (2005) explored aid growth relationship in macroeconomic level of 48 developing countries covering period 1970-1998 [21]. The study revealed that foreign aid is beneficial to the economic growth of developing countries but immediate and overall impact of aid on growth differs in terms of magnitude. Lohani (2004) measured the development using Human Development Index (HDI) of 120 countries with HDI value less than 0.800 in the year 2001 [22]. The finding revealed that foreign aid has a negative relationship with development The finding rather indicated that foreign direct investment and domestic investment plays a significant role in a countries development. Similar study was conducted by Chheange (2009) on 67 developing countries by using panel data from 1986-2005 and concluded that aid has no positive effect on economic growth, however, it is positively related to corruption [23].

In a regional context, Tait et al. (2015) empirically examined the impact of foreign aid of $25 \mathrm{Sub}$-Saharan African countries over the period of 1970-2012 through the fixed effect panel model [24]. The finding indicated that aid has a significant positive long term impact on per capita GDP of Sub-Saharan African countries. In addition, this study found that, aid in the form of grant was found to be more effective. In South Asian region, Sahoo (2016) examined long run causal relationship between foreign aid and economic development [7]. The study found that aid has significant positive impact in Sri Lanka; insignificant impact in India; significant but negative impact in Pakistan. Fatima (2014) found that foreign aid; neither at aggregate level nor at disaggregates level; had influence on economic growth in Pakistan [25]. Pant (2016) assessed the contribution of Japanese and US aid to the Nepalese economy [26]. It concluded that the overall contribution of foreign aid in Nepal was positive; however, less effective in aggregate.

\section{Methodology}

\subsection{The Model}

The theoretical foundation of the proposed study is based on growth model, which considers GDP (output) as a function of capital and labor, i.e.

$$
\mathrm{GDP}=\mathrm{f}(\mathrm{K}, \mathrm{L}, \mathrm{t})
$$

This is an aggregate production function which considers output as a function of capital (K) and labor (L). Capital comes from different sources as remittance, investment, foreign aid, and lagged GDP while labor comes from labor force. Inclusion of time $t$ in the model represents the shift in the basic production function that changes over the time i.e. $\mathrm{t}=1,2,3$, $4 \ldots . .$. [27]. The selection of these macroeconomic variables is also based on the literature reviews and availability of the reliable data set in the published sources.

The model specification of the study involves stock adjustment which facilitates to estimate speed of adjustment in GDP and, short and long run elasticity. The model indicates that desired level of GDP is reached actual GDP and some fraction of change known as speed of adjustment [28].

Introducing lagged GDP as an independent variable in the model will help to estimate the short and long term impacts of the variables and the speed of adjustment meaning adjustment of actual GDP to desired level of GDP by some factor say, $\lambda$. The value of $\lambda$ should lie in between one and zero. The process will help to examine economies of scale of the use of resources.

The regression model can be written as:

$$
\begin{array}{r}
\log (\mathrm{GDP})_{\mathrm{t}}=b_{0}+b_{1} \log (\mathrm{Aid})_{\mathrm{t}}+b_{2} \log (\mathrm{Inv})_{\mathrm{t}}+b_{3} \log \\
(\mathrm{Lab})_{\mathrm{t}}+b_{4} \log (\text { Remit })_{\mathrm{t}}+b_{5} \log \mathrm{GDP}_{\mathrm{t}-1}+\ldots+\mathrm{U}_{\mathrm{t}}(2)
\end{array}
$$

The coefficient of adjustment is obtained from $b_{5}$, which entails $(1-\lambda)$, its value normally ranging between 0 and 1 . The estimate of $b_{1}$ is foreign aid, $b_{2}$ is investment, $b_{3}$ is labor force, $b_{4}$ is remittance inflows; $\lambda$ is the speed of adjustment. The long run impact in all cases can be obtained by dividing the estimated $b$ 's by $\lambda$. The adjustment coefficient determines the relationship which should exist between the short and long- 
run impacts.

\subsection{The Data Sources}

Most of the studies are taking short time period for the empirical analysis. In case of annual time series data, minimum 30 years data should be considered to capture the appropriate long run trend among the variables [7]. Therefore, this paper aims to understand the status of foreign aid based on about past 40 years of data available, i.e. from 1975 to 2015 . Since this study is based on secondary data sources, the Economic surveys published by the Ministry of Finance and annual reports of Nepal Rastra Bank from year 1975/76 to 2015/16 are selected. All the relevant data for the study was available after year 1975 thus, sample period starts from this year.

\section{Data Analysis}

The production function which establishes the relationship between output and input has been the basis for measuring the impact of foreign aid received at various point of time. In addition to foreign aid ${ }^{1}$, other input variables included in the function are remittance (Remit as the indicator of Workers' Remittances), investment (Inv as the indicator of Total Investment and/ or Gross Fixed Capital Formation), labor force (Lab as the indicator of age group of 15- 59 years age group as economically active population), and lagged GDP $\left(\mathrm{GDP}_{\mathrm{t}-1}\right.$ indicator of a lag of one year).

All the variables have been converted into the real values (constant prices year 2001/02=100). After the process, the values of the variables have been converted in their logarithmic forms.

As per theoretical foundation, GDP is considered as the dependent variable whereas all other variables are used as the independent variables for the empirical analysis.

\subsection{Size, Status and Direction of Foreign Aid}

Foreign aid is considered as an important component of economic growth and social changes in Nepal from the beginning of planning exercises. Foreign aid is defined as the Official Development Assistance (ODA) channeled through the national budget in Nepal, constituting grants, loans and technical assistance by bilateral and multilateral organizations. The share of foreign aid as percentage of total budget is decreasing over a period of time as shown in table 1 . The table shows the data on five years span from 1975/76 to 2015/16 where the amounts are all converted to constant prices thereby using year 2001 as a base year.

It has been observed that foreign aid has increased by 6.81 times since year 1975. For detailed study, foreign aid has been sub- divided into foreign grants and loans where they increased by 4.1 times and 13.5 times respectively in year 2015 as compared to year 1975. However, foreign aid in

1 Aid is the indicator of foreign assistance which is the sum of foreign grants and foreign loans. relation to GDP has shown less significant change even though various fluctuations have been occurred during this period. This might have arisen since during this period, the amount of foreign aid was directed from manufacturing sector towards humanitarian sector. Moreover, the size of foreign grant has declined to $1.64 \%$ of GDP with increment of foreign loan to $2.20 \%$ of GDP. One of the reasons for this can be the mishandling of foreign funds leading to decrease in donor country's trust towards country's development.

\subsection{Commitment and Disbursement of Foreign Aid by Different Sources and Sectors}

The highest amount of commitment via bilateral source was in 1985/86 while the lowest commitment was done in 1975; and the highest amount of commitment via multilateral source was in 2010/11 while the lowest was in 1990. On the other hand, the highest amount of disbursement via bilateral source was in $1990 / 91$ with $84 \%$ disbursement of commitment while the lowest amount of disbursement was in year 2000 with only $16 \%$ as evident in table 2 . Similarly, the highest amount of disbursement via multilateral source was during year 2005/06 with $233 \%$ of disbursement of commitment whereas lowest amount of disbursement was $21 \%$ in year 1975 . In case of bilateral commitment, no $100 \%$ disbursement of the commitment was observed during any of the study year while there is more than $100 \%$ disbursement of multilateral commitment observed during some of the study year especially in the decades of 1990 s and early 2000 s. The reason for these highest disbursements exceeding $100 \%$ might be because of being final year of disbursement of the aid for many foreign and funded projects [33].

The trend of disbursement of commitment rate is fluctuating, where over a period of time; the interest has shifted from production sector to service sector. The disbursement- commitment rate decreased for agriculture, irrigation and forestry sector in 1975 from $181.6 \%$ to $50.7 \%$ while, the trend increased for transport, power and communication from $20.7 \%$ to $52.3 \%$. It can be observed that foreign aid priorities have shifted towards social services with $94.9 \%$. Here, social services include- rural development, water supply, education, and health. The figures from table 3 also demonstrate that there is no commitment on industry and mining in years 1995/96, 2000/01 and 2010/11. The sectors have been merged in one another for data consistency. From this, it can be interpreted that, the preference of foreign aid commitment and disbursement has shifted from production sector i. e. transport, power and communication sector to nonproduction sector i.e. social sector. Due to this, contribution of foreign aid to GDP has not increased during this study time as compared to other macro- economic variables.

Since foreign aid alone does not contribute in economic development, some other major economic variables are included as factors responsible for economic growth such as investment, remittance, labor force and lagged GDP (as presented in table 4). 
Table 1. Size of foreign aid from period 1975/76 to 2015/16 (in NRs millions).

\begin{tabular}{llllllll}
\hline Year & Foreign grant & Foreign loan & $\begin{array}{l}\text { foreign } \\
\text { assistance (aid) }\end{array}$ & $\begin{array}{l}\text { GDP (factor } \\
\text { cost) }\end{array}$ & $\begin{array}{l}\text { Foreign grant } \\
\text { as\% of GDP }\end{array}$ & $\begin{array}{l}\text { Foreign loan } \\
\text { as\% of GDP }\end{array}$ & $\begin{array}{l}\text { Foreign assistance } \\
\text { as\% of GDP }\end{array}$ \\
\hline 1975 & 2786.5 & 1131.0 & 3917.5 & 128510.0 & 2.17 & 0.88 & 3.05 \\
1980 & 5363.4 & 4279.5 & 9642.9 & 157193.2 & 3.41 & 2.72 & 6.13 \\
1985 & 4833.8 & 10307.6 & 15141.4 & 219309.9 & 2.20 & 4.70 & 6.90 \\
1990 & 5024.6 & 14522.1 & 19546.7 & 269535.7 & 1.86 & 5.39 & 7.25 \\
1995 & 6788.9 & 13315.7 & 20104.6 & 336818.9 & 2.02 & 3.95 & 5.97 \\
2000 & 6930.7 & 12360.3 & 19291.1 & 424284.1 & 1.63 & 2.91 & 4.55 \\
2005 & 11676.7 & 6936.6 & 18613.2 & 516059.9 & 2.26 & 1.34 & 3.61 \\
2010 & 21832.4 & 5741.0 & 27573.4 & 593553.8 & 3.68 & 0.97 & 4.65 \\
2015 & 11358.5 & 15309.3 & 26667.9 & 695213.5 & 1.63 & 2.20 & 3.84 \\
\hline
\end{tabular}

Source: Economic Survey Fiscal years 1995, 2001, 2008 and 2016, Ministry of Finance [29-32].

Table 2. Foreign aid commitment and disbursement by major sources

\begin{tabular}{|c|c|c|c|c|c|c|c|c|c|}
\hline \multirow{2}{*}{ Year } & \multicolumn{3}{|c|}{ Commitment (in NRs millions) } & \multicolumn{3}{|c|}{ Disbursement (in NRs millions) } & \multicolumn{3}{|c|}{ Disbursement as per\% of Commitmen } \\
\hline & Bilateral & Multilateral & Total & Bilateral & Multilateral & Total & Bilateral & Multilateral & Total \\
\hline 1975 & 595 & 820 & 1416 & 331 & 175 & 506 & 56 & 21 & 36 \\
\hline 1980 & 1916 & 2097 & 4013 & 858 & 704 & 1562 & 45 & 34 & 39 \\
\hline 1985 & 4656 & 4848 & 9504 & 1481 & 2010 & 3492 & 32 & 41 & 37 \\
\hline 1990 & 3495 & 2171 & 5665 & 2940 & 3050 & 5990 & 84 & 141 & 106 \\
\hline 1995 & 10356 & 6181 & 16537 & 3533 & 10756 & 14289 & 34 & 174 & 86 \\
\hline 2000 & 17496 & 13791 & 31287 & 2771 & 16026 & 18797 & 16 & 116 & 60 \\
\hline 2010 & 31824 & 74277 & 106101 & 25850 & 32147 & 57998 & 81 & 43 & 55 \\
\hline 2015 & 91069 & 104530 & 195599 & 27423 & 45350 & 72772 & 30 & 43 & 37 \\
\hline Total & 176163 & 214883 & 391046 & 72846 & 124602 & 197448 & 41 & 58 & 50 \\
\hline
\end{tabular}

Source: Ministry of Finance, Economic Survey, 2015/16 [11].

Table 3. Summary of Foreign aid commitment and disbursement by sectors

\begin{tabular}{|c|c|c|c|c|c|c|}
\hline \multirow{3}{*}{ Sectors } & \multicolumn{2}{|c|}{ Commitment (NRs millions) } & \multicolumn{2}{|c|}{ Disbursement (NRs millions) } & \multicolumn{2}{|c|}{ Disbursement as per\% of Commitment } \\
\hline & \multicolumn{6}{|c|}{ Years } \\
\hline & 1975 & 2010 & 1975 & 2010 & 1975 & 2010 \\
\hline Agriculture, Irrigation and Forestry & 68.9 & 5805.9 & 125.1 & 2941.7 & 181.6 & 50.7 \\
\hline Transport, Power and Communication & 1115.2 & 28374.3 & 230.7 & 14832.3 & 20.7 & 52.3 \\
\hline Industry and Mining & 6.6 & 0 & 62.3 & 0 & 943.9 & 0.0 \\
\hline Social Services & 125.1 & 32947.6 & 86 & 36402.9 & 38.2 & 94.9 \\
\hline Others & 100 & 38972.9 & 1.5 & 3821 & 1.5 & 9.8 \\
\hline
\end{tabular}

Source: Various Economic Surveys, MoF [11, 29-32].

Table 4. Foreign aid, investment and remittance (in NRs millions) as\% of GDP.

\begin{tabular}{lllllll}
\hline Year & Foreign assistance & Investment & Remittance & GDP (factor cost) & $\begin{array}{l}\text { Foreign Assistance } \\
\text { as\% of GDP }\end{array}$ & $\begin{array}{l}\text { Investment as\% } \\
\text { of GDP }\end{array}$ \\
\hline 1975 & 3918 & 12643 & 1792 & 128510 & 3.05 & $\begin{array}{l}\text { Remittance } \\
\text { as\% of GDP }\end{array}$ \\
1980 & 9643 & 29678 & 2989 & 157193 & 6.13 & 1.39 \\
1985 & 15141 & 43681 & 3334 & 219310 & 6.90 & 18.88 \\
1990 & 19547 & 58198 & 4940 & 269536 & 7.25 & 21.59 \\
1995 & 20105 & 95700 & 6027 & 336819 & 5.97 & 28.41 \\
2000 & 19291 & 101239 & 48456 & 424284 & 4.55 & 23.86 \\
2005 & 18613 & 148313 & 82493 & 516060 & 3.61 & 1.52 \\
2010 & 27573 & 246871 & 120544 & 593554 & 4.65 & 1.83 \\
2015 & 26668 & 264988 & 232597 & 695214 & 3.84 & 1.79 \\
\hline
\end{tabular}

Source: Various Economic Surveys, MoF.

As already explained, foreign assistance has increased by 6.8 folds from NRs. 3918 million to NRs 26,668 million thus contributing $3.84 \%$ to GDP in year 2015. Similarly, investment has also increased by about 21 times thereby contributing $38.12 \%$ to GDP compared to year 1975 . Remittance has also shown significant change with time where it increased its contribution to GDP from $1.39 \%$ in year 1975 to $33.46 \%$ in 2015 - i.e. about 130 times in year 2015.

\subsection{Regression Analysis}

The regression model has been employed to examine the 
impact of the variables. The specification of the model involves GDP at factor cost as dependent variable and foreign aid (Aid), remittance (Remit), investment (Inv), labor force (Lab) and lagged GDP (LGDP) as independent variables. It was hypothesized that all the independent variables in the model have significant positive impact on Nepalese economy which is a proxy by GDP. The regression result is given below:

$\ln (\mathrm{GDP})_{\mathrm{t}}=-11.94 *+0.06 \ln (\text { Aid })_{\mathrm{t}}-0.03 \ln (\text { Remit })_{\mathrm{t}}+0.04$ $\ln (\mathrm{Inv})_{\mathrm{t}}+1.17 \ln (\mathrm{Lab})_{\mathrm{t}}^{* *}+0.40 \ln (\mathrm{GDP})_{\mathrm{t}-1}+\ldots+\mathrm{U}_{\mathrm{t}}$ $\mathrm{t}=(-1.930)(1.105)(-0.793)(0.433)(2.259)(2.484)$

$\mathrm{R}^{2}=0.989 \mathrm{~F}=632.591$

$\mathrm{DW}=1.986$

$\mathrm{df}=34$

$\mathrm{N}=40$

Adjusted $\mathrm{R}^{2}=0.988$

$\mathrm{SEE}=0.05616$

Jarque- Bera $=17.35436$

Note: * Significance at 1 percent level

** Significance at 5 percent level

The regression result shows that the sign of all coefficients are positive except that of remittance. However, the coefficient is not significant. It may be due to larger portion of spending driven towards consumption. It seems that very limited amount of remittance is being invested in production activities.

All the variables included in the model shows the existence of regression. The $\mathrm{R}^{2}$ of the model estimation is obtained at 0.98 which indicates that 98 percent of the variation in GDP can be explained by the variation of independent variables used in the model. The computed $\mathrm{F}_{(5,39)}$ is 632.591 which is higher than the table value of $\mathrm{F}_{(5,39)}$. The model is best fit. Therefore, the hypothesis, that the coefficient of all the variables jointly or simultaneously, is not equal to zero. It confirms the presence of relationship between GDP and foreign aid, remittance, investment, labor force and lagged GDP.

The coefficient of lagged GDP is significant at 1 percent level which provides 0.396 value of coefficient. Based on this coefficient, the speed of adjustment is $(1-\lambda)=0.604$. It shows that $60.4 \%$ is adjusted to the desired level of GDP in the period included. Similarly, labor force (15- 59 years group) is also significant at 1 percent level while the coefficients of foreign aid and investment are not significant. However, the sign of coefficients are positive as per expectation. The reason for insignificant investment may be due to channelization of investment in real sector.

Table 5. Short- and Long- run analysis.

\begin{tabular}{lllll}
\hline Impact & $\begin{array}{l}\text { Foreign } \\
\text { Aid }\end{array}$ & Investment & Remittance & $\begin{array}{l}\text { Labor } \\
\text { force }\end{array}$ \\
\hline Short term elasticity & 0.056 & 0.036 & -0.026 & 1.169 \\
Long term elasticity & 0.093 & 0.06 & -0.043 & 1.94 \\
\hline
\end{tabular}

The coefficient of labor force (Lab) tells that 1 percent increase in labor force would lead 1.169 percent in the output (GDP) in short- run while in long- run this would increase to 1.94 percent. The findings of the model suggest that there is a need for emphasizing focused investment in close collaboration with government, private sector and development partners. There should also be emphasis for the productive use of remittance. The opportunities of remittance should be considered up to only medium term plan.

\subsection{Structural Breakthrough Analysis}

Another objective of the study was to see whether there is a presence of structural breakthrough in the Nepalese economy. A lot of reform measures took place during the restoration of democracy. The economic liberalization in the economy started with the implementation of structural adjustment programs by IMF and the World Bank which tied up many of its assistance program. As a result, convertibility of capital and current account reformed in external sector to have external assistance. In order to see structural change, a Chow test developed by Gregory C. Chow has been used. Nepal undertook economic stabilization and trade liberalization during 1991. Many reform measures were implemented during 1991. The sample data is thus divided into two time periods: First period from 1975/76 to $1991 / 92$ and Second period from $1992 / 93$ to $2015 / 16$; the pre- and postliberalization periods.

From this, three possible regressions are drawn:

First period 1975/76 to $1991 / 92:\left(\mathrm{n}_{1}=16\right)$

$$
\mathrm{GDP}_{\mathrm{t}}=\alpha_{1}+\alpha_{2}(\mathrm{Aid})_{\mathrm{t}}+\alpha_{3}(\text { Remit })_{\mathrm{t}}+\alpha_{4}(\text { Inv })_{\mathrm{t}}+\alpha_{5}(\mathrm{Lab})_{\mathrm{t}}+\alpha_{6}(\mathrm{GDP})_{\mathrm{t}-1}+\ldots . .+\mathrm{U}_{1 \mathrm{t}}
$$

Second period 1992/93 to 2015/16: $\left(\mathrm{n}_{2}=24\right)$

$$
\mathrm{GDP}_{\mathrm{t}}=\beta_{1}+\beta_{2}(\mathrm{Aid})_{\mathrm{t}}+\beta_{3}(\text { Remit })_{\mathrm{t}}+\beta_{4}(\mathrm{Inv})_{\mathrm{t}}+\beta_{5}(\mathrm{Lab})_{\mathrm{t}}+\beta_{6}(\mathrm{GDP})_{\mathrm{t}-1}+\ldots . .+\mathrm{U}_{2 \mathrm{t}}
$$

Whole period $1975 / 76$ to $2015 / 16:\left(n=\left(n_{1}+n_{2}\right)=40\right)$

$$
\mathrm{GDP}_{\mathrm{t}}=\gamma_{1}+\gamma_{2}(\text { Aid })_{\mathrm{t}}+\gamma_{3}(\text { Remit })_{\mathrm{t}}+\gamma_{4}(\mathrm{Inv})_{\mathrm{t}}+\gamma_{5}(\mathrm{Lab})_{\mathrm{t}}+\gamma_{6}(\mathrm{GDP})_{\mathrm{t}-1}+\ldots . .+\mathrm{U}_{\mathrm{t}}
$$

Regression (5) assumes that there is no difference between the two time periods and therefore estimates the relationship between foreign aid and economic growth for the time period consisting of 40 observations. In other words, the regression assumes that the intercept as well as the slope coefficient remains the same over the entire period; i. e. there is no structural change. If this is in fact the situation, then $\alpha_{1}=\beta_{1}=\gamma_{1}$ and $\alpha_{2}=\beta_{2}=\gamma_{2}$.

Regression (3) and (4) assume that the regressions in the two time periods are different; i. e. the intercepts and the slope coefficients are different, as indicated by the subscripted parameters. In the preceding regressions, the U's represent the error terms and the n's represent the number of observations. 
For the data given in table above, the empirical counterparts of the preceding three regressions are as:

For first period,

$\mathrm{GDP}_{\mathrm{t}}=-5.006-0.016(\text { Aid })_{\mathrm{t}}-0.016(\text { Remit })_{\mathrm{t}}+0.401(\mathrm{Inv})_{\mathrm{t}}$

$+0.623(\mathrm{Lab})_{\mathrm{t}}+0.272(\mathrm{GDP})_{\mathrm{t}-1}+\ldots+\mathrm{U}_{1 \mathrm{t}}$

$\mathrm{t}=(-0.239)(-0.089)(-0.077)(1.391)(0.389)(0.857)$

$\mathrm{R}^{2}=0.925 \mathrm{RSS}_{1}=0.074 \mathrm{df}=\left(\mathrm{n}_{1}-\mathrm{k}\right)=(16-6)=10$

For second period,

$\mathrm{GDP}_{\mathrm{t}}=-13.180-0.028(\text { Aid })_{\mathrm{t}}+0.009(\text { Remit })_{\mathrm{t}}+0.040(\text { Inv })_{\mathrm{t}}$

$+1.607(\mathrm{Lab})_{\mathrm{t}}-0.028(\mathrm{GDP})_{\mathrm{t}-1}+\ldots+\mathrm{U}_{2 \mathrm{t}}$

$\mathrm{t}=(-4.158)(-0.733)(0.636)(1.062)(5.353)(-0.172)$

$\mathrm{R}^{2}=0.997 \mathrm{RSS}_{2}=0.006 \mathrm{df}=\left(\mathrm{n}_{2}-\mathrm{k}\right)=(24-6)=16$

For whole period,

$\mathrm{GDP}_{\mathrm{t}}=-11.940+0.056(\text { Aid })_{\mathrm{t}}-0.026(\text { Remit })_{\mathrm{t}}+0.036(\mathrm{Inv})_{\mathrm{t}}$

$+1.169(\mathrm{Lab})_{\mathrm{t}}+0.396(\mathrm{GDP})_{\mathrm{t}-1}+\ldots+\mathrm{U}_{\mathrm{t}}$

$\mathrm{t}=(-1.930)(1.105)(-0.793)(0.433)(2.259)(2.484)$

$\mathrm{R}^{2}=0.989 \mathrm{RSS}_{\mathrm{R}}=0.107 \mathrm{df}=\left(\mathrm{n}_{1}+\mathrm{n}_{2}-\mathrm{k}\right)=(16+24-6)=34$

Since two sets of samples are deemed independent, $\mathrm{RSS}_{1}$ and $\mathrm{RSS}_{2}$ can be added to obtain unrestricted residual sum of square $\left(\mathrm{RSS}_{\mathrm{UR}}\right)$, i. e.

$\mathrm{RSS}_{\mathrm{UR}}=\mathrm{RSS}_{1}+\mathrm{RSS}_{2}=0.074+0.006=0.08$;

$\mathrm{df}=\left(\mathrm{n}_{1}+\mathrm{n}_{2}-2 \mathrm{k}\right)=16+24-12=28$

The idea behind the Chow test is that if in fact there is no structural change, and then the $\mathrm{RSS}_{\mathrm{R}}$ and $\mathrm{RSS}_{\mathrm{UR}}$ should not be statistically different. Thus, the following ratio is formed as:

$$
\mathrm{F}=\frac{\left(R S S_{R}-R S S_{U R}\right) / k}{\left(R S S_{U R}\right) /\left(n_{1}+n_{2}-2 k\right)} \text {, or } \mathrm{F}=\frac{(0.107-0.08) / 6}{0.08 / 28}=1.575
$$

From the F-tables, it is found that for degree of freedom (df) with 6 and 28, the 5 percent critical $F$ value is 2.45 . Therefore, the probability of obtaining an $\mathrm{F}$ value of as much as or greater than 1.575 is much smaller than 5 percent. The Chow test therefore seems to support the study hypothesis that foreign aid- GDP relationship has not undergone a structural breakthrough in Nepal over the period 1975/76 to $2015 / 16$, assuming that the assumptions underlying the test are fulfilled.

\section{Conclusion}

The findings of the study shows that there is a positive but not significant relationship between foreign aid and economic growth since foreign grant is increasing in lower rate than that of foreign loans. This study observed that foreign aid priorities has shifted from production to non- production i.e. humanitarian and social service sector thus contributing less to GDP as compared to other macro- economic variables as investment and remittance. In case of foreign assistance, foreign loan has increased tremendously as compared to foreign grants. This has increased the burden of debt on future generations.

However, the study shows that remittance has although not significant but negative relationship with GDP. This may be due to use of remittance inflows in consumption rather than investment. Meanwhile, labor force and lagged GDP shows significant positive relationship with GDP which implies that increasing labor force has led to increase in GDP and GDP from previous year is being used as capital in the current year.
During the analysis, it was also found that, the country has not undergone any structural breakthrough even after introducing various reform measures and undergoing economic stabilization and trade liberalization. This can mean that reform measures taken during that period has not been effective enough or requires more revision for practical implications.

\section{Declaration}

The views, conclusions, and recommendations derived here are the narratives concluded by the authors, based on the facts and figures derived in this paper, which do not reflect the official views and perspectives of the organizations where the authors are associated now. This study was conducted in early 2017 A. D. when Dr. Phuyal was in CEDA, and Ms. Pradhan was associated with AIM.

\section{References}

[1] Murshed, M., \& Khanaum, M. M. (2014). Impact of Foreign Aid in the Economic Development of Recipient Country. Journal of the Bangladesh Association of Young Researchers, 2 (1), 33-37.

[2] Elayah, M. (2016). Lack of foreign aid effectiveness in developing countries between a hammer and an anvil. Contemporary Arab Affairs, 9 (1), 82-99.

[3] Dornan, M., \& Pryke, J. (2017). Foreign Aid to the Pacific: Trends and Developments in the Twenty-First Century. Asia \& the Pacific Policy Studies, 4 (3), 386-404.

[4] Van Hoa, T. (2007). Foreign Aid and Development in Thailand: Causality and Political Economy. Thammasat Economic Journal (Thailand), 25 (4), 127-54.

[5] Fengler, W., \& Kharas, H. (2010). Overview: Delivering aid differently. Delivering aid differently: lessons from the field, $1-41$.

[6] Easterly, W. (2006). Planners versus searchers in foreign aid. Asian Development Review, 23 (2).

[7] Sahoo, K. (2016). Foreign Aid and Economic Development: Empirical Evidence from Select South Asian Economies. Unpublished PhD Thesis. National Institute of technology Rourkela.

[8] Giri A, Khatiwada P, Shrestha B, Chettri RK. (2013). Perceptions of government knowledge and control over contributions of aid organizations and INGOs to health in Nepal: a qualitative study. Global Health (2013) 9: 1. doi: 10.1186/1744-8603-9-1.

[9] Pandey, D., (1999). Nepal's Failed Development: Reflections on the Missions and Maladies. Nepal South Asia Centre, Kathmandu.

[10] Premaratne, D. \& Deshal, D. M. (2009). Migration and Remittances in South Asia, Policy Brief (No. 12). South Asia Watch on Trade, Economics \& Environment (SAWTEE).

[11] MoF. (2016). Economic Survey Fiscal Year 2015/16. Kathmandu: Government of Nepal. 
[12] Bhattari, B. P. (2005). Effectiveness of foreign aid: A case study of Nepal. A PhD Dissertation Submitted to School of Economics and Finance, University of Western Sydney, Australia.

[13] Bhatta, C. D. (2017). Critical Appraisal of Foreign Aid and Development in Nepal. in Gyanwali Ram Prasad (ed.). Political Economy of Nepal, Kathmandu: Tribhuvan University/FES Nepal Office.

[14] Nikku, B. R., \& Azman, A. (2014). Politics, Policy and Poverty in Nepal. International Journal of Social Work and Human Services Practice, 2 (2), 1-9.

[15] Bowen, W. G., Davis, R. G., \& Kopf, D. H. (1960). The Public Debt: A Burden on Future Generations?. The American Economic Review, 50 (4), 701-706.

[16] Otaki, M. (2015). Public debt as a burden on the future generation: A Keynesian approach. Theoretical Economics Letters, 5 (05), 651.

[17] Paudyal, S. B. (2013). Do Budget Deficits Raise Interest Rates in Nepal?. NRB Economic Review, 25 (1), 51-66.

[18] Phuyal, R. K. and Sunuwar, S.(2018). A sectoral analysis of foreign direct investment on economic growth of Nepal, Journal of Business and Social Sciences Research, 3 (1), 1-12.

[19] Ram, R. (2004). Recipient country's policies' and the effect of foreign aid on economic growth in developing countries: additional evidence. Journal of International Development, 16 (2), 201-211.

[20] Durbarry, R, Gemmell, N \& Grenaway, D. (1998). New evidence on the impact of foreign aid on economic growth. CREDIT Research Papers, 98 (8).

[21] Moreira, S. B. (2005). Evaluating the Impact of Foreign Aid on Economic Growth: A Cross- Country Study (1970- 1998). Setubal: School of Business Science.

[22] Lohani, S. (2004). Effect of Foreign aid on Development: Does more money bring more development? Illinois Wesleyan University: Honors Projects.
[23] Chheang, V. (2009). The effect of foreign aid on economic growth and corruption in 67 developing countries. Georgetown University. Retrived from https://repository.library.georgetown.edu/bitstream/handle/108 22/553686/chheangVanarith.pdf.

[24] Tait, L., Siddique, A., \& Chatterjee, I. (2015). Foreign Aid and Economic Growth in Sub- Saharan Africa. University of Western Australia.

[25] Fatima, F. (2014). Foreign aid and economic growth. Available at SSRN: https://ssrn.com/abstract $=2407348$ or http://dx.doi.org/10.2139/ssrn.2407348.

[26] Pant, K. D. (2016). Foreign aid to Nepal: A comparative study of Japanese aid and US aid. Unpublished PhD thesis. Tribhuvan Univeristy.

[27] Gillis, M., Perkins, D. H., Radelet, S., Roemer, M., Snodgrass, D. R. (2000). Economics of Development. New York: WW Norton \& Company Inc.

[28] Kumar, R. (1986). The Forest Resources of Malaysia. New York: Oxford University Press.

[29] MoF. (1996). Economic SurveyFiscal Year 1995/96. Kathmandu: Government of Nepal.

[30] MoF. (2006). Economic SurveyFiscal Year 2005/06. Kathmandu: Government of Nepal.

[31] MoF. (2009). Economic SurveyFiscal Year 2008/09. Kathmandu: Government of Nepal.

[32] MoF. (2012). Economic SurveyFiscal Year 2011/12. Kathmandu: Government of Nepal.

[33] Paudel, D. (2009). Foreign Aid and Economic Development in Nepal: A Revisit. PEFA Journal, 35- 42.

[34] Karkee, R., \& Comfort, J. (2016). NGOs, foreign aid, and development in Nepal. Frontiers in public health, 4, 177, 1-5.

[35] Papanek, G. F. (1972). The effect of aid and other resource transfers on savings and growth in less developed countries. Economic Journal, 82 (327), 935-950. 